\section{Wage inequality within and across firms: the role of market forces, government and firm policies}

\author{
Uta Schönberg \\ University College London, United Kingdom
}

Wage inequality has increased sharply in many industrialised countries over the past decades. In Germany, for example, real (i.e. inflation-adjusted) wages at the bottom 10 per cent of the wage distribution declined by more than 15 per cent between 1995 and 2010 , whereas real wages at the top 10 per cent of the wage distribution rose by more than 12 per cent over the sam period. Real wages at the middle of the wage distribution, at the median, remained roughly constant between 1995 and 2010, even though GDP grew by 1.24 per cent per year on average 2009; Kügler et al., 2018).

In addition to overall rising wage inequality, noticeable inequalities in employment and wages persist between men and women, and a large part of the gender gaps observed today in advanced countries can be attributed to the arrival of children. In West Germany, in particular, it is still common for women to withdraw from the labour market for an extended period after the birth of their first child. Once mothers return to the labour market, they often do so on a parttime basis to a lower-paying occupatio than the occupation in which they were employed before birth.
The goal of my ERC-funded research is first shed new light on the sources behind the rising overall and persistent gender inequalities in the labour market and second, to evaluate the effectiveness of government and firm policies aimed at tackling these inequalities. I put firms at re centre of the analysis. First, existing become increasingly dependent on where workers work, rather than on the skills that workers possess (e.g. Card al., 2013; Song et al., 2019). And second firms have a crucial role to play in tackling gender inequalities by providing policies and creating a work environment that supports mothers in balancing family and career.

My research is organised around three themes. In Part A, linvestigate the causes behind rising wage inequality between firms. In Part B, I investigate how two important policies currently high up the policy agenda, minimum wages and taxation of firms' profits, impact turn to gender gaps inside the firm and explore to what extent firm policies and the work environment shape mothers' careers after childbirth.

\section{Analysing wage inequality} on workers and firms. In Part C, I then

\section{Part A}

Increasing wage inequality across firms: causes

In a perfectly competitive labour market wages depend only on workers' skills but not the type of firm workers work for. Firms bid up workers' wages up until they are equal to the marginal revenue product of workers' labour. A growing concern among academics and policymakers alike is that we are increasingly moving away from this benchmark toward a monopsonistic labour market where workers are paid wages below the marginal revenue product of their labour while firms earn higher and higher profits. I first investigate whether and to what extent routine-biased techno what extent (RTC)-often technological change (RTC)-often seen as the key observed in the rise in wage inequality why wates have become increasing why wages have become increasingly de want hork fy ans inying differences between fins in terns of their size, the types of workers they employ, and the wages they pay to workers of the same type. Existing theoretical models of RTC can explain why wages have diverged across workers with different skills but not why wages of workers with similar skills have

diverged across firms. My proposed theoretical framework deviates from the benchmark of perfect competition with a representative firm assumed in mos existing models of RTC and incorporates RTC into a model with heterogeneous
firms where workers with the same skills firms where workers with the same skills are paid different wages across firms. then empirically validate the implication from the theoretical model drawing on high quality matched employer-employe data from Germany. The theoretic framework and empirical analysis allow me to address questions such as: Does RTC increase the sorting of more skilled workers to more productive firms? Does RTC increase the segregation of workers across firms such that more skilled workers are increasingly likely to work with each other? Does RTC lead to increased firm exits and in large firms? Does RTC increase wage dispersion across firms for the same worker type? And to what extent do these channels contribute to the overal rise in wage inequality across firms?

Second, I aim to directly quantify the extent the marginal revenue product of their labour and for which workers and firms, and in which markets, the wedge between workers' marginal revenue product and wages is highest. This is a challenging task near impossible to observe. My approach is based on the observe. My approach is based on the tight link between the the wer supply elasticity to the firm and the wedge between workers' marginal higher the the firm, the lower the monopsony power of firms, the more competitive the labour market, and the lower the wedge. I propose a novel methodology to estimate the labour supply elasticity to the firm, leveraging large idiosyncratic shocks to firms and linking increases in firm size to wage increases in the firm. The empirical analysis draws once again on high quality linssis draws once again data for Gemployee allows me to address questions such Has mon to address questions such as: wedge bopsony power, and hence the

marginal revenue product, increased over the in Germany-specifically so over the period 1995 to 2010 when median wages were stagnant and wage inequality rose sharply? Have langer fims more certain types of workers, such as women or low-skilled workers? And is monopsony power higher in more concentrated mets dominated by few firms?

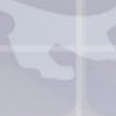

(8)
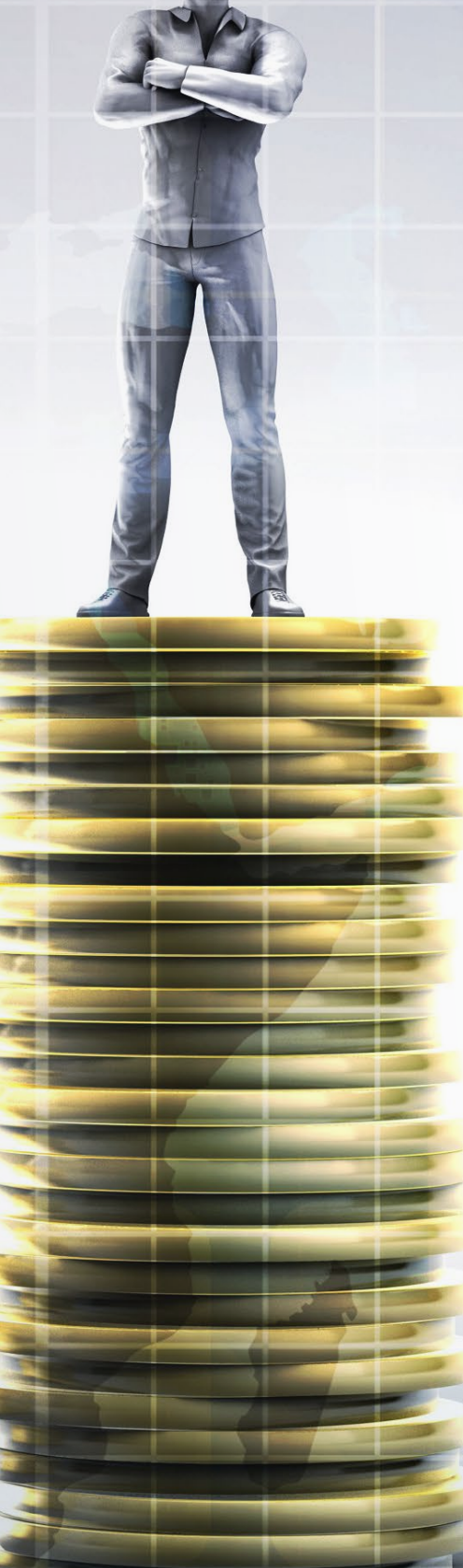
Part B

Government policies aimed at tackling wage inequalities across firms and curbing firms monopsony power

What can governments do to tackle wage inequality and curb firms' monopsony power? I evaluate two potential policies minimum wage policies and business taxation.

In a perfectly competitive labour market, a minimum wage will simply lead to more unemployment and ultimately leave lowwageworkersworse off.Inamonopsonistic labour market, in contrast, a minimum wage may curb the monopsony power of firms, increase wages of low-wage workers and reduce firms profits without lowering employment. I investigate the labour market effects of Germany's firsttime introduction of a minimum wage of $€ 8.50$ per hour on 1 January 2015 . The minimum wage cut deep into the wage distribution, affecting 15 per cen of workers. I focus on questions such as: Did the minimum wage increase wages of low-wage workers? Did it destroy the jobs of low-wage workers? Did the minimum wage induce small businesses to exit the market? Did the minimum wage have a different impact on large firms that may have more monopsony power than on small firms that pay wages close to workers' marginal revenue product? An did the minimum wage help reduce wase inequality within and between firms?

An alternative policy to curb monopsony power of firms could be to increase power of firms' profts. In Germany, tax rates levied on firms' profits vary locally, across municipalities, and over time as municipalities review their tax rates on an annual basis. I focus on sharp sudden and persistent tax changes across municipalities to address questions such as: Do higher business tax rates destroy or create jobs? Do firms shift the costs arising from higher business tax rates on to their workers by lowering workers' wages? Does an increase in the business tax rate differentially affect small and large proxy the share of colleagues with more firms, and skilled and unskilled workers? gender-egalitarian attitudes with the And does business taxation affect wage share of colleagues who grew up in East inequality within and between firms? Germany. As a state socialist country, East

Part C

The importance of

\section{firms in alleviating}

gender inequalities

In Part C, I shift the focus to one specific aspect of inequality-gaps in employment occupational choice between men and women. I investigate the role for in speeding up the return to work of mothers after childairth, in fostering mothers labour carket careers post-birth and ultimaty in reducing labour market s. Fist, fins can organise work in ways that are conducive or detrimental to combining family and career. For example, excessively long working hours are likely to discourage mothers to return to the firm after childbirth, while flexible working time arrangements, firm-financed or firm-provided childcare, or mentoring programmes may encourage them to do so. Drawing on survey data on firms that include detailed information on work organisation and family-friendly policies and that are linked to administrative data on the firms' employees, I address the following questions: Are family-friendly policies provided by firms successful at speeding up mothers' return to work after childbirth and continue to work in their pre-birth occupation possibly more so than one-size-fits-all government so licies? And do family-friendly policies help firms to attract and retain talent?

Firms, or workplaces, are also places where workers meet and interact, make friends and learn from each other. In a second step, I ask whether and to what extent co-workers affect mothers' post-birth careers. Specifically, I investigate whether colleagues who grew up in a more genderegalitarian environment and who hold more gender-egalitarian beliefs and values induce women from more traditional backgrounds to return to work faster and work longer hours after childbirth. I

\section{The bigger picture}

Overall, my research sheds novel light on 'big picture' questions such as: To what extent has RTC contributed to the rise in wage inequality not only across workers with different skills but also across firms among workers with similar skills? Has monopsony power of firms increased over time, allowing firms to pay wages below workers' marginal revenue product and to earn higher profits? Can minimum wage policies and higher tax rates on firms' profits curb monopsony power and firms' profits curb monopsony power and And is the lack of exposure to more And is the lack of exposure to more genderm firm the friche men and women?$$
\text { References }
$$

Card, D., Heining, J., and Kine P. (2013)
'Workplace heterogeneity and the rise of West 'Workplace heterogeneity and the rise of West
German wage inequality' Quarterly Journal of .

Dustmann, C., Ludsteck, J. and Schönberg, U (2009). Revisiting the German wage structure
Quartery J Jurnal of Economics, 124(2), 843-881. Kügler, A. Schönberg, U. and Schreiner, R. (2018). "Productivity growth, wage growth and unions: 20 June 2018, 215-247, European Central Bank Song, J., Price, D.J., Guvenen, F, Bloom, N. and
von Wachter, T. (2019). Firming Un Inequality.

14 von Wachter, T. (2019). Firming UD Inequality.
Quarterly Journal of Ecconomics, 1344(1), pp.1-50.
PROJECT NAME

FIRMINEQ - WAGE INEQUALITY WITHIN AND ACROSS FIRMS: THE ROLE OF FIRM POLICIES

PROJECT SUMMARY

The aim of my ERC-funded research is to first shed new light on the sources behind the rising overall and persistent gender to evaluate the effectiveness of government and firm policies aimed at tackling these finequalities. The focus is on Germany,
country that has experienced a particularly sharp increase in wage inequality and where the progress of women in the labour marled over the past three decades.

PROJECT LEAD

Uta Schönberg is a Professor of Economics at University College London and Deputy Analysis of Migration (CReAM). Her research interests are in labour economics and span topics such as wage inequality and wage dynamics; family and gender economics,
and the economics of migration. Professor and the economics of migration. Professor
Schönberg held positions as a Joint Managing Schönberg held positions as a Jon. Pritor at the Journal of Labor Economics and
Edito the Review of Economic Studies.

\section{PROJECT PARTNERS}

The project is based at the Department of Economics at University Coliege London and at the Centre for Research and Analysis of
Migration (CReAM). Collaboration partners Migration (CReAM). Collaboration partn
include Queen Mary University London, UK
(AB) the and the Institute of Employment Rese and the institute of Employny
(IAB) in Nuremberg, Germany.

CONTACT DETAILS

Uta Schönberg

University College London Gower Street, London, WC1E 6BT, United Kingdom

\section{IiII +442035495351}

u.schoenberg@ucl.ac.uk

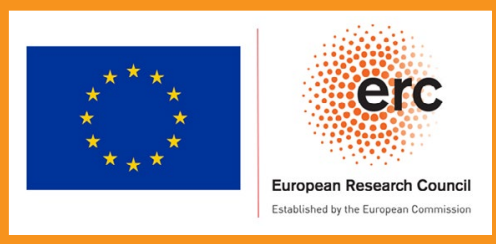

FUNDING

This project has received funding from the European
Research Council (ERC) under the European Union's Horizon 2020 research and innovation programme under grant agreement No. 818992. 